\title{
Kulturformidlingens transformation - folkebibliotekernes formidling i en digital tid
}

\begin{abstract}
The aim of this article is to investigate how the digital conversion that currently takes place in public libraries in Denmark, affects the perception of those cultural dissemination activities that result from the work with documents. My starting point is that the digital conversion means an increase in digital documents and that the characteristics of these documents differ so significantly from analog documents that it potentially means changes in both the practical handling and the conceptual universe associated with the designation, identification, and definition of practice. The study is conducted as a literature survey, where Johan Fjord Jensen (1988), Dag Solhjell (2001) and Jens Gudiksen (2005) constitute the theoretical framework and where eight public libraries' digital strategies from region Midtjylland are analyzed on the basis of a heuristic approach to the discourse concept. The conclusion is that the eight digital strategies do not explicitly refer to concepts that traditionally denote the cultural activities of the public library (e.g. 'enlightenment' and 'cultural activity') but that these concepts are thematized and understood in new and more transmissive terms such as 'accessibility' 'usage frequency' and as 'need', 'consumption' and 'demand'. This happens because the eight strategies consider technology and the use of technology superior to content, which makes the strategies more part of the public libraries' legitimization work and less a part of the facilitation of people's common actions in late modernity.
\end{abstract}

Keywords: Kulturformidling, kultursociologi, digitale dokumenter, folkebibliotek, digitale strategier, Danmark

\section{Indledning}

I Danmark har formidlingen af kultur været én af folkebibliotekets helt centrale samfundsfunktioner siden begyndelsen af 1900-tallet, hvor folkebiblioteket påtog sig at løse en række sociale og kulturelle opgaver for staten. Allerede i den første bibliotekslov fra 1920 forpligtede folkebiblioteket sig til at facilitere den almene befolknings livspraksisser, idet datidens bogsamlinger skulle: "... indeholde en Samling oplysende Litteratur af geografisk, historisk, og almindelig kulturhistorisk Art, Bøger om religiøse Spørgsmaal, Samfundets Ordning, Naturkundskab og de praktiske Erhverv." (Jensen, 1985, s. 39, min kursivering). Samtidig indledtes et tæt samarbejde med datidens oplysningsforbund, der varetog den efter- og videreuddannelse, som broderparten af (arbejder)befolkningen var forment adgang til indtil medio 1960'erne (Hvenegaard Lassen, 1962, s. 256; Jensen, 1985 , s. 66). Efter vedtagelsen af ny bibliotekslov i 1964 fik folkebiblioteket endvidere formelt til opgave at "fremme kulturel aktivitet". Det havde mange gjort i flere år, men med bibliotekslovens formulering ændrede 
kulturarbejdets status. Fra da af tolkedes biblioteksloven som det juridiske grundlag, der tillod folkebiblioteket en rolle som aktiv arrangør af for eksempel udstillinger, koncepter og foredrag (Jensen, 1985, s. 134-136).

Ovennævnte treenighed udgør i dag kernen i det senmoderne folkebiblioteks kulturformidlingsarbejde, idet opgaven stadig er at fremme oplysning, uddannelse og kulturel aktivitet. I dette arbejde har analoge dokumenter hidtil spillet en helt central rolle, idet disse aktiviteter initieres af, at folkebiblioteket stiller:

[...]bøger, tidsskrifter, lydbøger og andre egnede materialer til rådighed såsom musikbærende materialer og elektroniske informationsressourcer, herunder internet og multimedier. (Biblioteksloven, 2013, § 1).

De analoge dokumenter er den mest fremtrædende teknologi på folkebiblioteket målt i både antal, økonomi og udlån (Danmarks statistik, 2014; Styrelsen for Bibliotek og Medier, 2010, s. 35) og omdrejningspunkt for en stor del af folkebibliotekets kulturformidlende aktiviteter, men symbiosen mellem medieform og institution er under forandring.

I 2000'erne opstod en national ambition om at modernisere den offentlige administration, hvorfor Finansministeriet i 2011 valgte at etablere Digitaliseringsstyrelsen, hvis formål er: "...at digitalisere det offentlige Danmark og bidrage [...] til Finansministeriets mission om at styrke vækst og produktivitet samt sikre effektivisering af den offentlige sektor." (Digitaliseringsstyrelsen, 2016). I 2011 havde folkebiblioteket som sektor været i gang med en lignende proces i 15 - 20 år. I min optik faldt denne udvikling i tre faser: første fase var digitalisering af bibliotekarernes håndtering og organisering af de fysiske bestande i begyndelsen af 1990'erne, der siden resulterede i publikums adgang til digitale kataloger (OPACS), bibliografiske databaser og siden også Internet. Anden fase var forsøgene med udlån af e-bøger og adgang til fuldtekst databaser, der indledtes i perioden 2000 - 2002 og som siden 2004, med variationer (se f.eks. Balling m.fl., 2014 s. 12; Grøn \& Balling, 2016), har udgjort et fast bibliotekstilbud. Og tredje fase har vi været i siden ca. 2010, hvor den digitale omstilling har nået et niveau, der er ved at skabe en hybrid virkelighed, som påvirker folkebibliotekets generelle virksomhed herunder også dets kulturformidlende aktiviteter.

For at koordinere den strukturelle del af dette arbejde oprettede Kulturministeriet og Kommunernes landsforening i 2013 et forpligtende samarbejde i Danskerens digitale bibliotek, der: "...skal styrke bibliotekernes mulighed for at håndtere og formidle elektroniske medier såsom e-bøger og andre netbaserede materialer." (“Danskernes Digitale Bibliotek", 2016).

Som det ses af ovennævnte, er der i folkebiblioteket et overvejende fokus på, hvordan digitale teknologier kan effektivisere og rationalisere praksis, men hvad betyder den digitale omstilling for den måde folkebiblioteket betragter sine kulturformidlende samfundsopgave på? Og hvilke konsekvenser har implementering og den kvantitative forøgelse af digitale dokumenter for folkebibliotekets italesættelse af egne kulturformidlende praksisser? Formålet med denne artikel er at finde svar på ovennævnte ved at analysere otte folkebibliotekers digitale strategier, samt at studere hvad en sådan italesættelse kan indebære for publikums rolle i denne proces.

\section{Metodiske overvejelser}

Nærværende studie er gennemført som et dokumentarisk studie, hvori en kultur- og -formidlingsteoretisk tilgang danner grundlag for en analyse af otte midtjyske folkebibliotekers digitale strategier. Når valget falder på region Midtjylland, skyldes det at otte ud af sytten folkebiblioteker i regionen, har udarbejdet egentlige digitale strategier ved mine studiers begyndelse i 2015, og at disse strategier specifikt forholder sig til ovennævnte omstilling. Det er ikke tilfældet i nogen anden region i Danmark. Valget falder på strategier fordi det er her, de midtjyske folkebiblioteker italesætter intentioner og forventninger til fremtidens praksis. Gennemlæsning af strategierne er derfor foretaget med inspiration fra kulturanalysens heuristiske tilgang til kulturelle fænomener (Ehn \& Löfgren, 1982 s. 18 ff.), med henblik på at identificere hvor og hvordan strategierne italesætter, og eventuelt omfortolker begreberne "oplysning" og "kulturel aktivitet". Disse italesættelser forholdes til Dag Solhjells definitioner af henholdsvis "paratekst" og "kontekst" som væsentlige bestanddele i ethvert formidlingsarbejde, og hvis afdækning kan identificere hvordan, form og indhold håndteres. Denne metode er 
valgt, fordi den kan afdække de midtjyske folkebibliotekers diskursive fremstilling, samt hvordan den er under forandring af den digitale omstilling. Gennem analyser af dokumenter som for eksempel strategier er det muligt at identificere hvilke sproglige betegnelser, der anvendes til at beskrive og dermed legitimere forskellige aktiviteter og deres sammenhænge (se også Kann-Rasmussen \& Tank, 2016).

Til trods for at udviklingen af digitale dokumenter stadig er i sin vorden, og at den kultursociologiske impact stadig fremstår uklar, eksisterer der efterhånden en del forskning på området. I en dansk og nordisk kontekst iagttager jeg særligt tre perspektiver i den eksisterende forskning: 1) et læringsteoretisk-pædagogisk perspektiv, der fokuserer på hvilken indflydelse, anvendelsen af digitale dokumenter har for den enkeltes koncentrationsevne, tilegnelse af viden og kundskab, eller læring (se f.eks. Dahl \& Mangen, 2015; Mangen \& Kristiansen, 2013), 2) et mere domænespecifikt perspektiv, der fokuserer på digitaliseringens konsekvenser for produktion, organisation og distribution af oplevelser, viden og information, herunder også den kunstneriske krydsbefrugtning, der finder sted mellem forskellige medieformer og dokumenttyper (se f.eks. Gram, 2012; Grøn \& Balling, 2016; Nielsen, 2015), samt 3) et bredere kultursociologisk perspektiv, der vedrører digitale dokumenters potentialer i et senmoderne samfund (se f.eks. Grøn, 2010; Juncker, 2015; Mackey, 2012).

Nærværende artikel placerer sig i den sidste kategori. Jeg betragter digitale dokumenter som redskaber i den særlige form for blanding af kommunikation, interaktion og læring som kulturformidlingsarbejdet indeholder, og hvis formål er at facilitere menneskets håndtering af senmodernitetens konsekvenser.

\section{Teoretisk rammesætning}

Kultur som begreb

I indledningen gav jeg en kort beskrivelse af hvilke historiske processer, der førte frem til det kulturformidlingsbegreb, der i modificeret form stadig består, men hvad er kulturformidling egentlig? Både "kultur" og "formidling" er komplekse begreber, der har vist sig ganske vanskelige at definere. Kultur er et meget heterogent begreb, der er genstand for vedvarende diskussion (Sørensen, Høygård, Bjurström, \& Vike, 2008; Jantzen, 2005; Hastrup, 2004). I sin definition fra 1988 foreslår Johan Fjord Jensen, at der grundlæggende skelnes mellem et smalt kulturbegreb, hvor kultur betragtes noget, mennesket kan eje og et bredt kulturbegreb, hvor kultur betragtes som noget, mennesket kan være. I den smalle forståelse bliver kultur betragtet som lig med de genstande, der er resultatet af kunstneriske, systematiske eller akademiske aktiviteter. Når mennesket omgås sådanne genstande, sker der en tilegnelse, så dette menneske: "...bliver kulturel, får kultur, ja måske endda bliver 'kultiveret'. Kultur er i den betydning næsten et med dannelse." (J. F. Jensen, 1988, s. 158). I det brede kulturbegreb betragtes kultur som den helhed af vaner, rutiner og værdigrundlag, der karakteriserer forskellige fællesskabers livsmåder, og som gør os i stand til at se: "... gruppernes kultur som en helhed, forskellig fra andre kulturelle helheder ..." (J. F. Jensen, 1988, s. 158-159).

I folkebiblioteket har det smalle kulturbegreb langt hen ad vejen vundet hævd. Folkebiblioteket skal løse sine primære samfundsopgaver ved at stille bøger, tidsskrifter og lignende materialer til rådighed (Biblioteksloven, 2013, § 1), hvorved Lov om biblioteksvirksomhed stadfæster, at folkebibliotekets kulturformidlende arbejde sker gennem tilvejebringelse af dokumenter af forskellig art. Dertil kommer, at det smalle kulturbegreb er et instrumentelt begreb, der er praktisk anvendelig i planlægning, gennemførelse og evaluering af folkebibliotekets virksomhed: succes og fiasko kan måles kvantitativt via beholdning, antal arrangementer, udgift per borger, etc. hvilket sker gennem årlige indberetninger af statistiske nøgletal (Danmarks statistik, 2014).

\section{Formidling som begreb}

Der findes flere forskellige bud på, hvad formidling er (Hvenegaard Rasmussen, 2016; Drotner, 2006; Gudiksen, 2005), men alle tager udgangspunkt i formidling som en form for kommunikativ praksis. For nærværende har jeg indledningsvist valgt at lade mig inspirere af Dag Solhjells begreber om "paratekst" og "kontekst", som han identificerer $\mathrm{i}$ forbindelse med en kortlægning af den norske kunstformidlingsinstitution (2001). Solhjell beskriver, hvordan der eksisterer et rum mellem genstand og betragter, og hvordan dette rum udfyldes af formidler ved hjælp af "paratekster". En udstilling af for eksempel malerier er ikke andet end en samling rammer af træ med lærred påført maling, før formidler, ved hjælp af forskellige henvisninger, foretager en udpegning af 
de enkelte genstande som (kunst-)værker, der er værd at beskæftige sig med. Denne udpegning finder sted ved hjælp af forskellige teknikker (f.eks. lyssætning, kunstnerbiografier og værkforklaringer), og defineres af Solhjell som formidlingens "paratekster". Paratekster repræsenterer formidlingens form (2001, s. 20-40 og $82 \mathrm{ff}$.).

Formidlers udpegning af værker sker imidlertid altid ud fra bestemte opfattelser af værkerne, deres relationer til hinanden og til "virkeligheden". Denne relation kalder Solhjell for formidlingens "kontekst". Konteksten angiver, om der for eksempel skal foretages en stilmæssig, en æstetisk eller en kunsthistorisk læsning af udstillingen. Parateksterne peger altså på genstanden som værk, samtidig med at de angiver, i hvilken kontekst læsning af værket skal foregå. Konteksten kan træde mere eller mindre tydeligt frem i parateksterne, og betegnes som formidlingens indhold (2001, s. 20-40 og 131ff.). Formidleren formidler gennem valg af paratekster dermed både de udvalgte genstande som værker og betydningen af sin udvælgelse.

Dermed bliver formidling aldrig en uskyldig stillen-til-skue, men altid udtryk for det Solhjell, med reference til Pierre Bourdieu, kalder for symbolsk magtanvendelse, hvorfor det aldrig er ligegyldigt, hvem der har valgt, hvorfor der er valgt eller hvordan resultatet fremstilles:

Formidlermakt bør brukes med myndighet og kyndighet. Med makt følger også ansvar, særligt overfor kunstnere og publikum. Dette er mitt syn at kunstformidlere skal synliggjøre (...) den innflydelse de har over kunsten, kunstnerne og deres publikum, og ikke skjule den. Kunstformidlere bør være seg sin makt bevisst og bruke den åpent. Men makt over kunsten må kontrolleres og kritiseres, ellers blir makt til overgrep. (Solhjell, 2001, s. 18-19).

Når Solhjell er interessant i denne artikel, er det fordi hans genstandsbegreb, er mere anvendeligt i en digital kontekst end Fjord Jensens. I Fjord Jensens smalle kulturbegreb smelter form og indhold sammen til én samlet enhed i den genstand, hvorved mennesket danner sig. Analoge dokumenter kan godt betragtes som sådanne enheder, men det kan digitale dokumenter ikke. Jeg har derfor brug for et begrebsapparat, der kan håndtere adskillelsen mellem genstand og værk, og det kan Solhjells. Samtidig har jeg en antagelse om, at materialiteten "gør modstand" (Lövgren, 2004, s. 16ff.), hvilket vil sige at folkebibliotekets praktiske håndtering af henholdsvis analoge og digitale dokumenter, tager form efter disse dokumenters materialitet. Derfor må paratekster, som folkebiblioteket anvender til at udpege henholdsvis analoge og digitale dokumenter som værker, der er værd at beskæftige sig med, være forskellige. Endelig betyder Solhjells begrebsapparat at det bliver muligt at håndtere folkebibliotekets forskellige kulturformidlingsformer som kontekster igennem hvilke, folkebibliotekets holdning til dokumenterne som værker kan aflæses.

\section{Folkebibliotekets sociale og kulturelle berettigelse}

Med en ekskurs til Kirsten Hastrup (2004) vil jeg beskrive det danske samfund som senmoderne, demokratisk og bestående af en lang række (tilvalgs-)fællesskaber, hvori kulturelt determinerede mennesker deler sociale oplevelser af og erfaringer med, hvad verden er for et sted. Som mennesker har vi ingen adgang til hinandens kognitive strukturer, men ved at gøre os selv kommunikativt tilgængelige for hinanden bliver det muligt for os at interagere og udvikle os ved fælles hjælp (Hastrup, 2004, s. 9-17). Et givent fællesskabs værdigrundlag må konstrueres og løbende vedligeholdes af de mennesker, der indgår i det. Det sker, samtidig med at det givne fællesskabs normer og værdier virker tilbage på de mennesker, der indgår i det. Samtidig fungerer fællesskabet udgrænsende overfor mennesker, der ikke tilhører det givne fællesskab, hvorved de udgrænsede mennesker bliver "de andre", som det givne fællesskab kan spejle sig i (Hastrup, 2004, s. 10-11 og 19ff.).

Senmodernitetens fremkomst betyder blandt andet en forøget valgfrihed, hvad angår den enkeltes frivillige deltagelse i fællesskaber, og medfører en større kontaktflade mellem disse, da flere mennesker er aktive i flere forskellige fællesskaber samtidigt. Den udvidede kontakt bidrager til at afmontere den naturlighed, hvormed fællesskaber i førmoderne og moderne samfund overleverede deres traditioner. Senmodernitetens fremkomst betyder, at mennesker kommer til at leve langt mere ens end tidligere, men at de samtidig betragter hinanden som mere forskellige! (Hastrup, 2004, s. 9-17 og 41ff; se også Elias \& Scotson, 1994). Denne dobbelte oplevelse af at være ens $\mathrm{i}$ al vor forskellighed udgør en nødvendig baggrund for, at vi kan udvikle en refleksiv 
selviagttagelse, der er nødvendig for at kunne foretage kvalificerede til- og fravalg, der matcher vores individuelle og kollektive livspraksisser. I mødet med det anderledes bliver vi bevidste om, at der eksisterer andre opfattelser af og erfaringer med verden, og får samtidig mulighed for at reflektere over vore egne værdigrundlags arbitrære karakter. Som sådan bliver andre menneskers kulturelt betingede holdninger og handlinger principielt forståelige omend ikke altid lige acceptable (Hastrup, 2004, s. 15 og 69ff; se også Giddens, 1996). Refleksiv selviagttagelse er dermed afgørende for livet i senmoderniteten.

\section{Oplysning og kulturel aktivitet}

Den ovennævnte samfundsorganisering udgør den ramme, som folkebiblioteket må agere i. Folkebiblioteket skal stadig facilitere fællesskabsdannelse på baggrund af forestillinger om senmodernitet og valgfrihed, men på en sådan måde at der udøves den mindretalsbeskyttelse, der er indlejret i demokratibegrebet. I en senmoderne kontekst kan "oplysning" derfor defineres som facilitering af menneskets livsduelighed og selviagttagelse. Hvor det moderne folkebibliotek havde som formål at hæve det grundlæggende vidensniveau i befolkningen ved at sikre fri og lige adgang til oplevelser, viden og information, er det senmoderne folkebiblioteks formål i højere grad at facilitere menneskets bestræbelser på at foretage informerede og kvalificerede til- og fravalg, herunder også at tilbyde alternative perspektiver og tilgange. Det senmoderne folkebiblioteks oplysningsarbejde er dermed stadig rettet mod den enkelte, men med fællesskaber som referenceramme: oplysning kan betragtes som "noget" (oplevelse, information eller viden), "nogen" (bibliotekar eller formidler) har valgt, er vigtigere end andet, men hvor evaluering, accept eller afvisning nu er lagt i hænderne på den enkelte (publikum) (Kulturministeriet \& Center for Kultur- oplevelsesøkonomi, 2012, s. 4-7).

Livsduelighed og selviagttagelse er baggrunde for, at mennesker har mulighed for myndig deltagelse i samfundets kollektive og demokratiske processer. "Myndig deltagelse" fordrer kendskab til rækkevidden af egne muligheder og evner, samt viden om hvor, hvordan og hvornår engagement kan finde sted på adækvate måder. Hvor det moderne folkebibliotek, i samarbejde med oplysningsforbundene, havde som ambition at hæve befolkningens formelle uddannelsesniveau, vedrører det senmoderne folkebiblioteks uddannelsesbestræbelser både faglige færdigheder (læse-skrive-regne-IKT) og mulighederne for myndig deltagelse (Styrelsen for Bibliotek og Medier, 2010). For nærværende interesserer jeg mig kun for den myndige deltagelse, hvorfor uddannelsesaspektet lades ude af betragtning.

Myndig deltagelse fordrer en ramme, hvori mennesker kan involvere sig, og en sådan ramme faciliterer folkebiblioteket gennem tilbud om "kulturel aktivitet". Hvor det moderne folkebibliotek især bestræbte sig på at tilbyde kunstneriske, æstetiske og klassiske kulturoplevelser til et (mere) passivt publikum, er det senmoderne folkebibliotek i langt højere grad fokuseret på inddragelse, interaktion og medskabelse (Kulturministeriet \& Center for Kultur- oplevelsesøkonomi, 2012). Ved at give mennesker et rum at engagere sig $\mathrm{i}$ åbner folkebiblioteket op for lokale eksperimenter med sociale og kulturelle praksisser. Dorte Skot-Hansen, Casper $\mathrm{H}$. Rasmussen og Henrik Jochumsen har tidligere identificeret fire forskellige rum hvori folkebibliotekets kulturelle aktiviteter finder sted (Styrelsen for Bibliotek og Medier, 2010, s. 45-48). Hvert af disse rum kan være fysisk, digitalt eller hybrid, men alle kan fungere som sociale og kulturelle laboratorier.

Ovennævnte samfundsopgave løses altid under hensyntagen til folkebibliotekets ressourcer. Da folkebiblioteket er en offentligt finansieret velfærdsinstitution, er der en løbende diskussion af, hvordan dets virksomhed afvikles mest hensigtsmæssigt (læs: effektivt og rationelt), hvilket er en diskussion, der kan spores tilbage til folkebiblioteket etablering i forrige århundrede (se også Lund \& Audunson, 2001, s. 88-117). Sådanne diskussioner vedrører organisering af folkebibliotekets lokale, regionale og nationale (og siden også internationale) virksomhed, herunder standardisering og centralisering af redskaber, procedure, processer, etc. Diskussionen handler, dengang som nu, om at økonomisere folkebibliotekets drift og udvikling.

\section{Analoge og digitale dokumenters paratekster}

Ovenfor hævdede jeg en overensstemmelse mellem analoge dokumenter og det smalle kulturbegreb, men hvad er baggrunden for denne antagelse? Skabelse af skønlitterære, faglige og videnskabelige arbejder fordrer enten kreative, systematiske eller akademiske arbejder, der alle er kendetegnet ved at være forholdsvist 
ressourcekrævende. Fastholdes resultaterne af disse arbejder $\mathrm{i}$ analoge dokumenter, kan arbejdet betragtes som genstandsgjort, idet dokumentet i en formidlingsproces fremstår som et samlet værk, hvori den skabende værdi sammen med den fysiske fremstillings- og distributionsproces er nedlagt som symbolske repræsentationer. Folkebibliotekets håndtering af analoge dokumenter tager samtidig form efter disse værkers genstandskarakteristika og der organiseres gennem kataloger, klassifikations- og opstillingssystemer. Disse organiseringer kan, jævnfør Solhjell, betragtes som paratekster, der udpeger analoge dokumenter som værker, der er værd at beskæftige sig med, og samtidig implicit indeholder informationer om, i hvilken kontekst kulturformidlingen skal læses.

Fastholdes resultaterne af disse arbejder $i$ digitale dokumenter, betyder det en kraftig reduktion af ressourceforbruget til fremstilling og distribution, hvorfor digitale dokumenter fremstår som analoge dokumenters naturlige arvtager (Bog- og Litteraturpanelet, 2015, s. 7). Ved første øjekast er det udelukkende materialiteten, der ændres, fordi det kun er fremstillings- og distributionsprocesser, der berøres af digitalisering. Den kunstneriske, systematiske eller akademiske skabelsesproces forudsættes uforandret. Robert Willim definerer imidlertid digitale ressourcer ud fra tre karakteristika: behovet for "automatiske korrektioner", dets "modularitet" og "diskretion" (2002). Digitale ressourcer er afhængige af, at der finder en ubrudt række af "automatiske korrektioner" sted; aktivering af en ressource udløser de processer, der i sidste ende fører til en fremstilling af dokumentet som om det udgør én samlet enhed. Denne automatisering er nødvendig, fordi digitale ressourcer består af forskellige "moduler", der lagres som data, og det er disse modulers relationelle samspil, som automatiseringen styrer. Når dette er muligt, skyldes det at data er udskiftelige. Den mindste enhed, bit'en, kan manipuleres uafhængigt af resten af indholdet, og bliver således en forudsætning for, at digitale ressourcer kan tilgængeliggøres på forskellige platforme (smartphone, tablet eller computer). Den er, med Willims betegnelse, "diskret" (Willim, 2002, s. 82ff). Disse karakteristika er betingelsen for, at Willim definerer digitale ressourcer som "repræsentationer" og ikke som genstande. Willims definition vedrører digitale ressourcer $\mathrm{i}$ al almindelighed og dermed også digitale dokumenter.

Hos digitale dokumenter kan der derfor ikke på samme måde iagttages en overensstemmelse mellem værk og genstand eller mellem form og indhold. Digitale dokumenters repræsentative karakter tematiserer konstant adskillelsen mellem det kunstneriske, systematiserende eller akademiske indhold og den mediemæssige form, indholdet repræsenteres i. Også for digitale dokumenters vedkommende tager folkebibliotekets håndtering farve af dokumentets karakteristika, hvor organisering sker via hardware, software og databaseadgange. Disse kan også, jævnfør Solhjell, betragtes som paratekster, men da digitale dokumenter fremstår som processuelle og ikke-afsluttede repræsentationer, bliver spørgsmålet, hvad det digitale dokuments paratekster egentlig udpeger som "værk", og hvilken kontekst denne udpegning refererer til? Svaret er af afgørende betydning for folkebibliotekets kulturformidlende arbejde og for publikums mulighed for at iagttage de magtperspektiver, der ligger bag.

\section{Folkebibliotekets formidlingsformer som kontekst}

Parateksterne udpeger i hvilken retning folkebibliotekets kulturformidlende arbejde skal læses, og dermed i hvilken kontekst dette arbejde skal forstås. Ifølge Jens Gudiksen (2005) eksisterer der tre forskellige tilgange til formidlingsprocessen: en transmissiv, en hermeneutisk og en forandringsmæssig.

I en læsning af kulturformidling som transmission kan formidling opfattes som udvendige overførelser af oplevelser, viden og information. Udebliver den ønskede effekt, skyldes det mangler hos enten afsender, modtager eller den kanal hvori formidlingen finder sted (se også Hvenegaard Rasmussen, 2016, s. 28-41; Drotner, 2006, s. 8-15).

I en læsning af kulturformidling som hermeneutiske processer kan formidling opfattes som en (om end) anden form for udvendig udveksling af oplevelse, viden og information, hvor vægten ligger på dialogiske processer, hvori indholdet fortolkes som mening og forståelse. Udebliver den ønskede effekt, kan det skyldes manglende intellektuelle, kulturelle og/eller sociale forudsætninger hos deltagende parter (se også Hvenegaard Rasmussen, 2016, s. 28-41; Drotner, 2006, s. 8-15). 
I en læsning af kulturformidling som forandringsprocesser kan formidling opfattes som et indvendigt forhold ved menneskers kommunikative væren. Formidling bliver her til de handlinger, der skaber forandring hos de mennesker, der deltager. Menneskets handlinger er generelt flertydige, og hvad enten vi forstår dem eller ej, tolker vi dem ud fra forestillinger om intention og hensigt. Når vi gør det, sker der en individuel refleksion hos os, der skaber entydighed i vores forståelse af andre mennesker, men også af os selv! Derved lukkes handlingers åbne kontingens (Gudiksen, 2005, s. 35-36).

I et overordnet perspektiv betyder en transmissiv læsning af kulturformidling, at folkebiblioteket kan betragtes som en senmoderne og veldrevet offentlig virksomhed, hvis kulturformidling primært, men ikke kun, er bundet til et smalt kulturbegreb, og finder sted $\mathrm{i}$ en instrumentel kontekst. Fokus er på hvordan folkebiblioteket overfører oplevelser, viden og information så effektivt og rationelt som muligt. Det betyder ikke fravær af overvejelser over, hvorfor kulturformidling har en berettigelse, blot at opmærksomheden er på, hvordan folkebiblioteket agerer ressourcemæssigt ansvarligt.

I samme overordnede perspektiv betyder en forandringslæsning af kulturformidling, at folkebiblioteket kan betragtes som en ligeledes senmoderne, men også velfærdsstatslig institution hvis raison d'être primært, men ikke kun, er bundet til et bredere kulturbegreb. Her betragtes folkebiblioteket i en generativ kontekst, med vægt på hvorfor folkebiblioteket faciliterer menneskets individuelle og kollektive forandringsprocesser. Det betyder ikke fravær af overvejelser over, hvordan det kulturformidlende arbejde kan rationaliseres og effektiviseres, blot at der er opmærksomhed på folkebibliotekets samfundsmæssige funktion.

I et overordnet perspektiv betyder en hermeneutisk læsning af kulturformidling at folkebiblioteket både kan betragtes som en senmoderne og veldrevet offentlig virksomhed, og en velfærdsinstitution. Den hermeneutiske læsning placerer sig imellem en instrumentel og en generativ kontekst.

Den transmissive og den generative kontekst har været aktive simultant gennem store dele af folkebibliotekets historie (Lund \& Audunson, 2001, s. 88-117). Spørgsmål vedrørende hvordan har været besvaret ved hjælp af instrumentelle argumenter, og spørgsmål vedrørende hvorfor har været besvaret ved hjælp af generative argumenter - indtil nu. For noget tyder på, at balancen mellem de to kontekster er under forandring. I det følgende skal det vises hvordan den digitale omstilling, som den kommer til udtryk i otte folkebibliotekers digitale strategier, bidrager til denne omfortolkning. I næste afsnit analyserer jeg nemlig, hvordan en række midtjyske folkebiblioteker indenfor de sidste 3-4 år har genfortolket relationen mellem folkebibliotek og publikum under indtryk af disse nye vilkår.

\section{"Livsduelighed" og "selviagttagelse" i en digital praksis}

Fordi mit fokus er lagt på de områder af kulturformidlingen, der påvirkes af folkebibliotekets digitale omstilling, har jeg valgt at analysere otte midtjyske folkebibliotekers digitale strategier for at iagttage, hvordan de italesætter deres implementering af digitale dokumenter. Da strategierne er udarbejdet på institutionsniveau og i overensstemmelse med kommunale digitaliseringsstrategier, udtrykker de ikke nødvendigvis hverken samme fokus eller niveau, men ambitionen er fælles, hvilket blandt andet kommer til udtryk i forordet til Herning bibliotekernes strategi:

Vi ønsker at vores brugere skal opleve et bibliotek, hvor det digitale tilbud er ligestillet med det fysiske tilbud. Det betyder at vi skal kunne formidle de digitale tilbud til vores brugere lige så sikkert og professionelt som vi hidtil har gjort i forhold til de fysiske bibliotekstilbud.

Det betyder også at brugernes benyttelse af vores digitale tilbud skal øges. Vi ønsker at de digitale tilbud skal blive lige så udbredte og kendte som de fysiske tilbud. Vores $\emptyset$ nske er at åbne brugernes $\varnothing j n e$ for den palet af muligheder, som de digitale tilbud giver dem i hverdagen. Bl.a. at det digitale tilbud giver mulighed for at benytte bibliotekstilbuddet uden om rammerne for det fysiske bibliotek. Kort sagt: uafhængigt af tid og sted (Herning bibliotekerne, 2014, s. 3). 
Når strategier er valgt som udgangspunkt for denne analyse, er det, fordi de er offentligt tilgængelige, og fordi det er her, de midtjyske folkebiblioteker tydeligst italesætter, hvordan de forholder sig til konsekvenserne af deres digitale omstilling. Strategierne vedrører flere forhold end det publikumsrettede formidlingsarbejde hvorfor afsnit, der har andre foci, udelades af analysen.

I de otte strategier er der især tre tematikker, der er interessante i forhold til "livsduelighed" og "selviagttagelse": 1) "mediernes ligestilling", 2) aktivering af "ikke-biblioteksvante målgrupper" og 3) "øget kendskab og brug" af digitale dokumenter.

Ad 1) Formuleringen om "mediernes ligestilling" henter sin legitimitet i Lov om biblioteksvirksomhed, og stadfæster, at det ikke er teknologien, men derimod indholdet der skal gøres til genstand for vurdering, når det indgår i en formidlingskontekst. Herning bibliotekerne formulerede dette i deres forord (se citatet ovenfor), og Randers bibliotekerne er enig: "Det digitale og det fysiske bibliotek er ligestillede i vores prioritering og er gensidigt afhængige størrelser i det moderne bibliotek." (Randers Bibliotek, 2013).

Ringkøbing-Skjern biblioteker udtrykker en lignende ambition om: "...ligestilling af fysiske og digitale materialer. Det er indholdet og ikke mediet, der er det afgørende. Der tages højde for ligestillingen bl.a. i forbindelse med materialevalg." (Ringkøbing-Skjern Bibliotekerne, 2014).

I Favrskov bibliotekerne er: "...indholdet, ikke mediet [...] afgørende." (Favrskov Bibliotekerne, 2014).

Ad 2) Folkebiblioteket er for alle, men omkring $1 / 3$ af den voksne befolkning benytter det aldrig (Styrelsen for Bibliotek og Medier, 2010, s. 33-39). Derfor ser flere af de midtjyske folkebiblioteker den digitale omstilling som en mulighed for at nå "ikke-biblioteksvante målgrupper" (Knudsen, 2014, s. 15 og 22). Herning bibliotekerne tænker disse målgrupper ind $\mathrm{i}$ alle dele af strategien:

Vi skal have kendskab til brugernes og ikke-brugernes digitale behov og kompetencer og sætte fokus på, hvordan vi med de digitale tilbud kan skabe merværdi for brugerne. (Herning bibliotekerne, 2014, s. 4).

Odder bibliotekerne vil: "...'opdyrke' nye målgrupper" (Odder Bibliotek, 2014), mens Randers bibliotekerne er "...ops $\varnothing$ gende og afprøvende omkring nye kommunikationskanaler til borgerne og vil bruge sociale medier både til formidling og til dialog med borgerne." Resultaterne af indsatsen skal gerne kunne aflæses på "benyttelsesandel", der fremover vil blive monitoreret via "måltal" (Randers Bibliotek, 2013).

Skive bibliotekerne vil ud fra samme formål: "...bruge netmedier til at nå nye målgrupper..." (Skive Bibliotek, 2013) og endelig vil Viborg bibliotekerne: "...bruge digitale medier til at nå nye eller truede målgrupper." (Viborg bibliotekerne, u.å.). Hvilke målgrupper der er tale om, hvordan de skal nås og hvad der truer hvem hos Viborg bibliotekerne, defineres ikke.

Ad 3) Hvis folkebibliotekets benyttelsesfrekvens skal fastholdes eller forøges, kræver det, at publikum bliver bekendt med de muligheder, der eksisterer. I flere af strategierne er der indføjet rudimentære markedsføringsplaner. I forordet til Herning bibliotekernes strategi var dette udtrykt som et $\varnothing$ nske om at gøre opmærksom på de muligheder, som digitale tilbud giver. Odder og Viborg biblioteker vil: "...formidle og markedsføre netmedier og licenser..." (Odder Bibliotek, 2014; Viborg bibliotekerne, u.å.), mens Horsens: "...vil markedsføre og formidle de digitale tilbud og de relevante teknologiske platforme, over for borgerne..." (Horsens Bibliotek, u.å.).

Skive bibliotekerne vil: "...øge kendskabet til netmedier både internt i biblioteket og eksternt i forhold til brugerne..." (Skive Bibliotek, 2013). 
Intetsteds i de midtjyske folkebibliotekers strategier italesættes "livsduelighed" eller "selviagttagelse" som begreber, heller ikke i deres historiske form som "oplysning", og der er ingen tanker om hvorfor digitale dokumenter er anvendelige i facilitering af menneskets livspraksisser i det senmoderne. Derimod formuleres, som det fremgår af ovenstående citater, en hel del omkring "tilgængelighed" og "benyttelse" både i forhold til eksisterende målgruppers aktuelle og ikke-biblioteksvante målgruppers potentielle benyttelsesfrekvens. Henvisningerne til mediernes ligestilling er hos flere af de midtjyske folkebiblioteker formuleret som en måde hvorpå de frie og lige adgang til oplevelser, viden og information gøres uafhængig af tid og sted. Men i denne bestræbelse sker paradoksalt nok det modsatte: i stedet for at rette fokus mod indhold, (over-)betones formen! Denne betoning kan blandt andet iagttages i den måde, begreberne "formidling" og "markedsføring" anvendes synonymt. Det er iøjnefaldende når Odder, Horsens og Viborg bibliotekerne, i en digitaliseringsstrategi (og ikke markedsføringsstrategi) vil "...formidle og markedsføre..." netmedier og licenser, mens Randers biblioteker "...leverer og formidler alle typer digitalt biblioteksindhold..." (Randers Bibliotek, 2013). Herning bibliotekerne er endnu mere udtalte i deres formuleringer og vil:

\begin{abstract}
...udarbejde[r] 'personaer', der repræsenterer forskellige målgrupper, hvorefter virkelige repræsentanter for disse personaer, i udvalgte perioder udsættes for 'maksimum push' [...]. Maksimum push er en salgsstrategi, der er hentet fra detailhandlen og indebærer at der 1) udarbejdes en række personaer som målgrupper inddeles efter, 2) at der etableres et katalog over digitale ressourcer som en enkelte personakategori forventes at være interesseret i og at der 3) udarbejdet et katalog over situationer, hvor personakategorier kan pares med potentielt interessante digitale ressourcer. I den personlige betjening er det bibliotekarens rolle altid at tilbyde borger de digitale tilbud, som vedkommende, qua sin indplacering i bestemte personaskategorier, potentielt har interesse for (Herning bibliotekerne, 2014, s. 6-7).
\end{abstract}

Fokus ligger her eksplicit på en kvantitativ forøgelse af benyttelsesfrekvens, og midlet er aggressiv markedsføring af digitale dokumenter til eksisterende og nye målgrupper. Hvilke kvalitative fordele digitale dokumenter har for publikum og hvorfor ikke-biblioteksvante skal motiveres til at anvende dem, beskrives ikke.

Ovennævnte udtrykker en forskydning af oplysningsbegrebet i retning af tilgængelighed og benyttelse. Strategierne tager alle afsæt $i$ et smalt kulturbegreb, hvor publikums omgang med digitale dokumenter som genstande er i fokus, og hvor kulturformidling således betragtes ud fra en transmissiv læsning (kontekst). Finder denne promovering sted for at facilitere menneskets oplysning, livsduelighed eller selviagttagelse? Måske, men i så fald skyldes det en indforstået antagelse om, at større tilgængelighed til og øget benyttelse af digitale dokumenter $i$ sig selv fremmer disse kompetencer. I dén henseende er det en transmissiv kontekst, der optræder i strategiernes italesættelse af formidlingspraksis (parateksterne).

\title{
"Kulturel aktivitet" og "myndig deltagelse" i en digital praksis
}

Ovenfor definerede jeg "kulturelle aktiviteter" som sociale laboratorier, hvori mennesker kan opøve livsduelighed, ud $\varnothing$ ve selviagttagelse og gøre sig praktiske erfaringer med myndig deltagelse i samfundsprocesser. Når kulturelle aktiviteter er interessante i nærværende sammenhæng, er det fordi den praktiske udfoldelse af disse, ofte har det analoge dokument (bogen) eller andre genstande som omdrejningspunkt og fælles referenceramme.

Heller ikke "kulturelle aktiviteter" defineres i de midtjyske strategier, hvorfor jeg af sammenhængen må udlede, hvilke tanker der er gjort om dette. De afsnit der er mest interessant, vedrører 1) strategiernes beskrivelser af "communities" og 2) deres fokus på "behov, brug og efterspørgsel".

Ad 1) De mest eksplicitte beskrivelser af communities finder jeg hos Herning bibliotekerne og i Randers bibliotekernes satsninger på sociale medier, herunder Facebook. Opbygning af communities har baggrund $\mathrm{i}$ teorierne om brugerdrevne innovationsprocesser, som folkebiblioteket indenfor de seneste 10 år er begyndt at anvende strategisk (Brug brugerne i biblioteket, 2008; Kulturministeriet \& Center for Kultur- oplevelses $\emptyset$ konomi, 2012), både i udvikling af publikumsrettede tilbud og som monitoreringsmetode. Herning bibliotekerne $\emptyset$ nsker at benytte begge aspekter: 
Vi ønsker at opbygge et online community omkring de digitale ressourcer på HeB [Herning bibliotekerne] med det formål at styrke synligheden omkring ressourcerne og skabe en samlet platform for udveksling og know how ift. brugen af dem. Målgruppen for dette community er primært biblioteksbrugerne; sekundært personalet. (Herning bibliotekerne, 2014, s. 9)

Selvom Herning bibliotekerne hverken definerer ikke-bruger som kategori, eller forholder sig til hvordan et community i sig selv skal tiltrække ikke-biblioteksvante målgrupper og motivere aktuelle målgrupper til at $\emptyset$ ge deres benyttelse eller hvorfor det er relevant, så er formålet, at community'et skal fungere som et interaktivt rum, hvori publikum kan udfolde sig kulturelt i en digital kontekst. Samtidig skal community'et fungere som en monitoreringsmetode for bibliotekarerne til at opnå nye viden publikums benyttelsesm $\varnothing$ nstre:

Desuden er det et $\emptyset$ nske, at vi med dette community får mulighed for at styrke værdiskabelsen ved brugen af de digitale ressourcer, så værdien ikke kun knytter sig til den konkrete brug men også et før, under og efter via en relationsskabelse $\mathrm{ml}$. personale/brugere, bruger/bruger og ikke mindst personale/personale, med ressourcerne som omdrejningspunkt (Herning bibliotekerne, 2014, s. 9).

Randers bibliotekerne vil etablere deres community på Facebook og herigennem facilitere relationer mellem mennesker, samt mellem publikum og bibliotekar: "Vi vil i perioden lave Danmarks bedste lokale biblioteksside på Facebook. Vi vil løbende vurdere vores engagement på andre sociale medier end Facebook." (Randers Bibliotek, 2013). Hvad kriteriet for "Danmarks bedste lokale biblioteksside" er, defineres ikke.

Ad 2) Ud over community-begrebet er der en række andre udtryk, der kan anvendes til at illustrere de midtjyske folkebibliotekers opfattelse af publikumsrelationen. De udtryk der går igen, er "behov", "forbrug" og "efterspørgsel". Favrskov bibliotekerne ønsker at kunne foretage: "...hurtige, behovsstyrede ændringer i fordelingen..." (Favrskov Bibliotekerne, 2014), når der opstår situationer, hvor benyttelsesfrekvensen af digitale dokumenter ikke harmonerer. Hvordan disse forandringer skal monitoreres for at komme til bibliotekarernes kendskab, fremgår ikke. Samme ønske har Horsens bibliotekerne, men her anvendes: "...månedlige opgørelser, der analyserer brugsandel, ressourceforbrug og markedsudvikling for de digitale indholdsprodukter..." til at ressourcestyrer efter. (Horsens Bibliotek, u.å.). Randers bibliotekerne: "...laver månedlige opgørelser, der analyserer brugsandel, ressourceforbrug og markedsudvikling for de digitale indholdsprodukter og ressourcestyrer efter det." (Randers Bibliotek, 2013).

Ringkøbing-Skjern bibliotekerne vil opbygge et beredskab, hvor de: "...agerer hurtigt på ændringer i lånernes efterspørgsel af digitale medier." (Ringkøbing-Skjern Bibliotekerne, 2014), men beskriver heller ikke nærmere, hvordan deres monitorering skal gennemføres. Herning bibliotekerne vil blandt andet benytte indmeldelsesproceduren til: "...afdækningen af borgerens digitale behov og kompetencer..." (Herning bibliotekerne, 2014, s. 6) og samtidig præsentere bibliotekets digitale tilbud.

Ovenfor henviste jeg til en række eksempler på "rum", som folkebiblioteket gennem en 15-20 årig periode har identificeret sig selv $\mathrm{i}$ forhold til, og som giver publikum mulighed for at eksperimentere med myndig deltagelse i sociale, kulturelle og demokratiske processer (Styrelsen for Bibliotek og Medier, 2010, s. 45-48). Ingen af strategierne forholder sig til disse rum, men både Herning og Randers bibliotekernes communities kan betragtes som tiltag, der blandt andet skal promovere myndig deltagelse og fælles engagement. Her flugter strategierne tilsyneladende Gudiksens tredje, generative perspektiv (kontekst). Men også her drejer beskrivelserne hurtigt i retning af communities som rum for markedsføringsaktiviteter og som kilde til monitorering af publikum. Denne iagttagelse underbygges af strategiernes betoning af "behov, forbrug og efterspørgsel" som udgangspunkt for de forskellige formidlingsaktiviteter, hvor formålet igen er at markedsføre teknologien som form (hardware, software, struktur, etc.) og formidle kompetencer i at anvende disse (paratekster).

Samtidig er det indholdsmæssige fokus alene determineret af publikums benyttelsesfrekvens, hvorfor forbrug og efterspørgsel er udslagsgivende for hvilket indhold, der skal leveres. I forhold til kulturel aktivitet og 
folkebiblioteket som eksperimentarium for sociale og kulturelle interaktionsprocesser anlægger strategierne den samme transmissive karakter (kontekst) som skitseret ovenfor, hvor der, med kraftig inspiration fra sociale mediers fascinations- og tiltrækningskraft, fokuseres på, hvordan publikum skal motiveres. Igen kommer argumentationen om, hvorfor det er folkebibliotekets opgave at tilbyde alternativer til allerede eksisterende sociale medier, eller hvilket udbytte publikum har af folkebiblioteks tilstedeværelse på Facebook til at fremstå implicit.

\section{Diskussion}

\section{Paratekster}

Folkebibliotekets fokus på digitale dokumenter fremstår som et indlysende rigtigt skridt: det har altid været kutyme at anvende de nyeste teknologier for at rationalisere og effektivisere løsningen af folkebibliotekets samfundsopgaver, og implementering af digitale dokumenter kan betragtes som en videreførelse af denne bestræbelse. Da mængden af oplevelser, viden og information på grund af digitaliseringen samtidig er kraftigt for opadgående, bliver den tiltagende vanskelige at opbevare og umulig at overskue ved hjælp af konventionelle analoge teknologier. Og er der noget, den digitale teknologi kan, udover at lette produktion og distribution, så er det at håndtere, systematisere og lagre dokumenter, og reducere de enorme mængder tekst, billeder, film og lyd til overskuelige og håndterbare klynger.

De konkrete former som håndtering af digitale dokumenter antager, er udtryk for kulturformidlingens paratekster, der peger på hvordan digitale dokumenter skal fortolkes som genstande, der er værd at beskæftige sig med. Som allerede nævnt eksisterer det intellektuelle værk adskilt fra sin form, når det fastholdes digitalt, hvilket vanskeliggør formidlers entydige udpegning af, hvorfor det digitale dokument er værd at beskæftige sig med. I analysen af otte midtjyske folkebibliotekers strategier beskrev jeg, hvordan oplysningsarbejdet kom til at dreje sig om markedsføring og benyttelsesfrekvens. Dermed befordres adskillelsen fordi strategierne fokuserer på hvordan brugen af digitale dokumenter kan fremmes, samtidig med at hvorfor stort set negligeres. Er der begrundelser af hvorfor denne forøgelse er vigtig, er argumentationen generelt relateret til digitale dokumenters uafhængighed af tid og sted, hvilket vedrører folkebibliotekets eksistensberettigelse og ikke facilitering af publikums håndtering af senmoderniteten. Jeg beskrev endvidere, hvordan det snævre fokus på hvordan fjerner fokus fra indhold og retter det mod form, hvilket er stik mod hensigterne i de midtjyske folkebibliotekers egne formuleringer og lovgivningens intentioner.

Det er muligt at forestille sig to udløbere af denne udvikling: 1) at platforme, deres hardware og software fremover bliver betragtet som en del af de paratekster, der, sammen med databaser, søgemaskiner og hjemmesider, peger på et indhold, der er værd at beskæftige sig med som værk. I et sådant perspektiv må værkbegrebet redefineres på grund af dets repræsentative og dynamiske karakter eller 2) at det er platformene, deres hard- og software, der betragtes som de genstande, parateksterne peger på, hvorved indholdet indoptages i formen (McLuhan, 2013; se også Gram, 2012). I mine iagttagelser af de midtjyske folkebiblioteker syntes det sidste at være tilfældet. Her er aktiviteterne stort set udelukkende rettet imod hvordan digitale dokumenter bliver tilgængelige og anvendelige for publikum.

\section{Kontekst}

Med baggrund i parateksterne kan jeg nu diskutere hvilken kontekst, de midtjyske folkebibliotekers strategier henviser til. Strategierne betoner i særlig grad publikums muligheder for adgang hjemmefra, for adgang udenfor bemandet åbningstid og for at få opfyldt deres behov og efterspørgsel - når blot der er tale om et digitalt forbrug! Den digitale omstilling som strategierne er udtryk for, bibeholder derved et smalt kulturbegreb. Samtidig anlægges en transmissiv forståelse af oplevelser, viden og information som distribuerbar, hvilket reetablerer det enkelte menneske som objekt for folkebibliotekets handlinger.

At arbejde efter en sådan kontekst giver en række udfordringer som folkebiblioteket må adressere. Når kulturformidling planlægges og gennemføres i en transmissiv kontekst, forsvinder de generative argumenter, der har udgjort et af hovedargumenterne for folkebiblioteket eksistensberettigelse gennem hele det 20. århundrede, og efterlader folkebiblioteket $i$ en legitimitetskrise. I senmoderne samfund er det ikke tilstrækkeligt at 
argumentere med, at folkebiblioteket er en effektivt og rationelt drevet offentlig virksomhed, der skaber fri og lige adgang til oplevelser, viden og information. Dels gør Internettet det samme med langt større effektivitet og tiltrækningskraft, dels gør en sådan argumentation ikke rede for folkebibliotekets samfundsberettigelse, og dels åbner folkebiblioteket en flanke for beskyldning om konkurrenceforvridende virksomhed fra private udbydere. (se f.eks. Lerche \& Mønsted, 2015; Mønsted \& Lerche, 2015).

En anden udfordring vedrører det kvalitative indhold af kulturformidlingen. Oplysningsarbejdet definerede jeg ovenfor som en facilitering af menneskets livsduelighed og selviagttagelse, ud fra en antagelse om at oplysning altid er oplysning om noget, som nogen har valgt, er vigtigere end andet - også i en digital kontekst. Denne kvalificering giver indholdet en kvalitativ, men også kollektiv karakter, hvorfor autoriteten hos den der vælger, vedkommendes formidlingsform og oplysningens indholdsmæssige kvalitet skal kunne identificeres og diskuteres offentligt, jævnfør Solhjell (2001). Men det kan den kun blive, hvis autoriteten er synlig, kendt og indenfor rækkevidde. Bibliotekspersonalets direkte involvering i valg og fravalg af materiale og i deres samtidige deltagelse i kulturformidlingsarbejdet synliggjorde formidler, og placerede vedkommende indenfor rækkevidden af potentiel kritik. Dette potentiale forsvinder, når der henvises til eksterne leverandører af digitale dokumenter og når kulturformidlingsaktiviteterne digitaliseres. Det er stadig menneskeskabte algoritmer, der ligger bag de automatiske processer og digitale dokumenters organisering, ranking og $\varsigma \varnothing$ gbarhed, hvilket giver alle muligheder for at udtrykke kvalitetsdomme og bias. Ved teknologien mellemkomst fremstår sådanne domme imidlertid både objektive og neutrale. I et Solhjellsk perspektiv løber folkebiblioteket dermed en risiko for at forholde publikum væsentlige indsigter i og mulighed for at diskutere kulturformidlingens indhold. Herved bliver den digitale omstilling til et demokratisk problem, der vedrører menneskers myndige deltagelse i samfundsprocesser.

En tredje udfordring udgør de midtjyske folkebibliotekers fokusering på "behov, forbrug og efterspørgsel". Når disse tre begreber bliver bestemmende for hvilke dokumenter og aktiviteter, der tilbydes, bliver det implicit flertallets præferencer, der eksponeres. Denne eksponering er selvforstærkende (vi kommer til at leve mere ens), men risikerer samtidig at skabe polarisering mellem en majoritet og "dem", der ikke deler majoritetens holdninger og handlinger (vi betragter hinanden som mere forskellige) (Hastrup, 2004, s. 9-17 og 41ff.). Svaret på denne udfordring var i mange år, at der bliver taget hensyn til specifikke behov, så snart de melder sig (se for eksempel Pors, 1994, s. 141), men spørgsmålet er om det er korrekt. Jævnfør Hastrup er valg og fravalg styrede af det enkelte menneskes $\emptyset$ nsker, men også altid underlagt forskellige fællesskabsstrukturer. Ved at anvende forbrug eller efterspørgsel som styringselementer i kulturformidlingen gør folkebiblioteket sig potentielt blind for alternative perspektiver og målgruppers kollektivers forsøg på at imødegå senmodernitetens uhensigtsmæssigheder på andre måder.

\section{Konklusion}

Indledningsvist satte jeg mig for at undersøge, hvad den digitale omstilling - som den formuleres i otte folkebibliotekers digitale strategier - betyder, for den måde folkebiblioteket betragter sine kulturformidlende aktiviteter på. Formålet var at studere, hvilke konsekvenser implementering og forøgelse af digitale dokumenter har for folkebibliotekets italesætte af deres kulturformidlende virksomhed, og hvilken rolle publikum kan komme til at spille i dén proces. I den indledende redegørelse for hvordan kulturformidling udvikler sig fra at vedrøre et resultatorienteret oplysningsarbejde $\mathrm{i}$ begyndelsen af det 20. århundrede til den mere procesorienterede kulturformidling, der finder sted aktuelt, identificerede jeg folkebibliotekets traditionelle kulturbegreb som smalt og enten baseret på en transmissiv eller en generativ tilgang.

Min antagelse om at italesættelsen af folkebibliotekets kulturformidlingsform ændrer sig, når medieformen skifter fra analog til digital, viste sig at holde stik. Ved at iagttage hvilke paratekster de midtjyske folkebiblioteker anvender i deres omgang med digitale dokumenter, var jeg i stand til at identificere, hvordan de midtjyske folkebiblioteker udpeger teknologien som det, der er værd at beskæftige sig med. Min analyse afslørede endvidere, at de midtjyske folkebiblioteker i deres digitale strategier formulerer deres kulturformidlende aktiviteter ind i en transmissiv kontekst, hvorfor kvantitativ forøgelse af tilgængelighed og benyttelsesfrekvens bliver selvstændige mål, mens indholdet dikteredes ud fra forbrug og efterspørgsel. 
Den digitale omstilling, som den formuleres i de otte undersøgte digitale strategier bibeholder og forstærker dermed et smalt kulturbegreb, med fokus på hvordan det digitale dokument kan $\varnothing$ ge transmission af oplevelse, viden og information, hvilket reetablerer mennesket i disse otte dokumenter som objekt for folkebibliotekets kulturformidlings- og markedsføringsaktiviteter. Spørgsmål om hvorfor digitale dokumenter og heraf afledte aktiviteter er væsentlige for mennesker og fællesskaber i senmoderne samfund, lades i de unders $\varnothing$ gte tekster i overvejende grad ude af betragtning.

Denne betoning af teknologiske og det individualistiske aspekter i de otte unders $\varnothing$ gte dokumenter resulterer i en række udfordringer, der blandt andet vedrører folkebibliotekernes generelle legitimitet, menneskets myndige deltagelse i kollektive samfundsprocesser og imødegåelse af senmodernitetens uhensigtsmæssigheder.

Som det fremgår af dette studie, er der stadig mange ubekendte, når det handler om digitale dokumenter og folkebibliotekernes digitale strategier. Denne artikel ønsker derfor, at bidrage til den videre diskussion af kulturformidlingens transformation i en digital tid.

\section{Referencer}

Balling, G., Dahl, T. A., Höglund, L., Lund, H., Mangen, A., \& Nilsson, S. K. (2014). E-bogen : skandinaviske perspektiver på forskning og uddannelse. Nordisk tidsskrift for informationsvidenskab og kulturformidling, 3(1), 5-19.

Biblioteksloven (2013). Bekendtgørelse af lov om biblioteksvirksomhed. LBK nr. 100 af 30/01/2013.

Bog- og Litteraturpanelet. (2015). Bogen og litteraturens vilkår 2015, Bog- og Litteraturpanelets årsrapport. S.I.: Kulturstyrelsen.

Brug brugerne i biblioteket. (2008). Om brugerdrevet innovation. Hentet fra http://brugbrugerne.dk/ombrugerdreven-innovation.html

Dahl, T. A., \& Mangen, A. (2015). Deep Reading i biblioteket: et kritisk lys på håndteringen av e-bøker i fag- og folkebibliotek. Nordisk tidsskrift for informationsvidenskab og kulturformidling, 4(1), 5-21.

Danmarks statistik. (2014). Folkebibliotekernes nøgletal. Hentet fra

http://www.danmarksstatistik.dk/da/Statistik/emner/biblioteker/folkebiblioteker

Danskernes Digitale Bibliotek. (2016). Hentet 28. april 2017, fra

http://www.danskernesdigitalebibliotek.dk/hvad/

Digitaliseringsstyrelsen. (2016). Hentet 28. april 2017, fra https://www.digst.dk/Servicemenu/Om-os

Drotner, K. (2006). Formidlingens kunst: formidlingsformer og børnekultur. I Larsen, H. \& Børnekulturens Netværk, Når børn møder kultur, en antologi om formidling i børnehøjde (s. 8-15). København: Børnekulturens netværk.

Ehn, B., \& Löfgren, O. (1982). Kulturanalys : ett etnologiskt perspektiv (Uppl. 1:4). Malmö: Liber.

Elias, N., \& Scotson, J. L. (1994). The Established and the Outsiders. London: SAGE Publications Ltd.

Favrskov Bibliotekerne. (2014). Digital strategi for netmedier og licenser. Hentet fra http://centralbibliotek.dk/sites/default/files/legacy/digital_strategi_for_netmedier_og_licenser.favrskov_bibli otek_-_kort_udgave.pdf

Giddens, A. (1996). Modernitet og selvidentitet. København: Hans Retizels Forlag. 
Gram, L. K. (2012). Er biblioteket performancelitteraturens bogomslag? Nordisk tidsskrift for informationsvidenskab og kulturformidling, 1(1/2), 81-89.

Grøn, R. (2010). Oplevelsens rammer : former og rationaler i den aktuelle formidling af skønlitteratur for voksne på danske folkebiblioteker : ph.d. afhandling fra forskningsprogrammet Videnskultur og vidensmedier på Danmarks Biblioteksskole. Aalborg: Det Informationsvidenskabelige Akademi.

Grøn, R., \& Balling, G. (2016). Kampen om eReolen : biblioteker, bogmarked og framing af det litterære kredsløb. Nordisk tidsskrift for informationsvidenskab og kulturformidling, 5(3), 53-68.

Gudiksen, J. (2005). Formidling: En karakteristik af forskellige formidlingsforståelser og deres kommunikationsteoretiske og forskningstypologiske grundlag. Dansk Biblioteksforskning, 31-40.

Hastrup, K. (2004). Kultur: det fleksible fællesskab. Aarhus: Aarhus universitetsforlag.

Herning bibliotekerne. (2014). Digital strategi: Herning bibliotekerne - Danmarks bedste digitale bibliotek. Hentet fra http://centralbibliotek.dk/sites/default/files/legacy/herning_bibliotekernes_digitale_strategi_cb.pdf

Horsens Bibliotek. (u.å.). Digital strategi Horsens Bibliotek. Hentet fra

http://centralbibliotek.dk/nyheder/digitale-strategier-fra-bibliotekerne-i-cb-omr\%C3\%A5de-midtjylland

Hvenegaard Lassen, H. (1962). De danske folkebibliotekers historie 1876-1940. København: Dansk Bibliografisk Kontor.

Hvenegaard Rasmussen, C. (2016). Formidlingsstrategier : en grundbog om kulturinstitutioners formidling. Frederiksberg: Samfundslitteratur.

Jantzen, C. (2005). Tertium datur: kampen om kulturbegrebet. I A. Scott Sørensen (Red.), Kunstkritik og Kulturkamp (s. 85-103). Aarhus: Klim.

Jensen, E. A. (1985). Til bibliotekssagens fremme - træk af Bibliotekstilsynets historie indtil 1970. Christiansfeld: Edvard Pedersens Biblioteksfond.

Jensen, J. F. (1988). Det dobbelte kulturbegreb: den dobbelte bevidsthed. I H. Horstb $\varnothing \mid l$ (Red.), Kulturbegrebets kulturhistorie (s. 155-191). Aarhus: Aarhus Universitetsforlag.

Juncker, B. (2015). Digital youth : a challenge to cultural policy and cultural dissemination addressing children and young people in the nordic countries. Nordisk tidsskrift for informationsvidenskab og kulturformidling, 4(2), 20-28.

Kann-Rasmussen, N., \& Tank, E. (2016). Strategi som legitimitetsarbejde : strategiske svar på bibliotekernes udfordringer. Nordisk tidsskrift for informationsvidenskab og kulturformidling , 5(3), 5-19.

Knudsen, H. M. (2014). Bibliotek \& borger : du er altid velkommen. Kbh: Danmarks Biblioteksforening.

Kulturministeriet \& Center for Kultur- oplevelsesøkonomi. (2012). Reach Out: Naviger i brugerinddragelse og brugerdrevet innovation. Hentet fra http://www.cko.dk/sites/default/files/reach_out_inspirationskatalog_1.pdf

Lerche, A., \& Mønsted, S. (2015). Hvad er godt og hvad er mindre godt ved eReolens nye aftale? Perspektiv, 20-22.

Lund, N. W., \& Audunson, R. A. (2001). Det siviliserte informasjonssamfunn : folkebibliotekenes rolle ved inngangen til en digital tid. Bergen: Fagbokforlaget. 
Lövgren, O. (2004). Tingens tingslighet. I Kragelund, M., Ting og tingester: Materielle kulturstudier. (s. 13-26). Kbh: Danmarks pædagogiske universitet.

Mackey, M. (2012). Where in the new literary world are we? Nordisk tidsskrift for informationsvidenskab og kulturformidling, 1(1/2), 7-17.

Mangen, A., \& Kristiansen, M. (2013). Tekstlesning på skjerm: noen implikasjoner av et digitalt grensesnitt for lesning og forståelse. Norsk pedagogisk tidsskrift, 52-62.

McLuhan, M. (2013). Understanding Media: The Extensions of Man. New York: Gingko Press. Hentet fra http://kbdk.eblib.com/patron/FullRecord.aspx?p=1222206

Mønsted, S., \& Lerche, A. (2015, 17 dec). Det går (for) godt for eReolen. Hentet 10. oktober 2016, fra http://bf.dk/FagmagasinetPerspektiv/Bladet/2015/Perspektiv11/DetGaarForGodtForEReolen

Odder Bibliotek. (2014). Digital strategi for Odder Bibliotek. (2014). Hentet fra http://centralbibliotek.dk/sites/default/files/legacy/digital_strategi.odder bibliotek.pdf

Pors, N. O. (1994). Tilgængelighed og græsning; om bibliotekets brugere, materialer og servicekvalitet. Ballerup: Danmarks Biblioteksforening.

Randers Bibliotek. (2013). Digital strategi for Randers Bibliotek 2013-14. Hentet fra http://centralbibliotek.dk/sites/default/files/legacy/digital_strategi_2013-2014.randers_bibliotek.pdf

Ringkøbing-Skjern Bibliotekerne. (2014). Ringkøbing-Skjern Bibliotekerne Digital strategi. Hentet fra http://centralbibliotek.dk/nyheder/digitale-strategier-fra-bibliotekerne-i-cb-omr\%C3\%A5de-midtjylland

Skive Bibliotek. (2013). Digital strategi Skive Bibliotek 2013-2015. Hentet fra http://centralbibliotek.dk/nyheder/digitale-strategier-fra-bibliotekerne-i-cb-omr\%C3\%A5de-midtjylland Solhjell, D. (2001). Formidler og formidlet : en teori om kunstformidlingens praksis. Oslo: Universitetsforlaget. Styrelsen for Bibliotek og Medier. (2010). Folkebibliotekerne i videnssamfundet: rapport fra Udvalget om folkebibliotekerne i videnssamfundet. København.

Sørensen, A. S., Høygård, O. M., Bjurström, E., \& Vike, H. (2008). Nye Kulturstudier: en innføring. Oslo: Spartacus Forlag AS/Scandinavian Academic Press [Elektronisk resurs].

Viborg bibliotekerne. (u.å.). Strategi for digitale netmedier og e-ressourcer. Hentet fra http://centralbibliotek.dk/nyheder/digitale-strategier-fra-bibliotekerne-i-cb-omr\%C3\%A5de-midtjylland Willim, R. (2002). Framtid.nu: flyt och friktion i ett snabbt företag. Stockholm/Stehag: Brutus Östlings Bokförlag Symposion. 